\title{
Stock market scandal shakes telecommunications executives
}

Tokyo

THE chairman of Nippon Telegraph and Telephone (NTT), Japan's domestic telecommunications giant, last week became the latest victim of a stock market scandal that has shaken the Japanese government and industry.

The company at the centre of the stock scandal is Recruit Co., prominent in Japan's booming information industry. Between 1984 and 1986, Recruit sold millions of shares in Recruit Cosmos, a realestate subsidiary, to prominent leaders in government, industry, universities and the media, before the shares became available to the general public. Many of the buyers made large profits in October 1986, when the shares went on public sale at a premium.

Senior NTT officials feature prominently among recipients of the shares. It is widely believed that Recruit sold them the shares to win help in entering the lucrative telecommunications market following the privatization of NTT in 1985. Recruit leases high-speed digital communication lines from NTT and re-sells them to companies for video conferences and meetings at rates far below those of NTT.

Last week, Dr Hisashi Shinto, chairman of NTT, resigned after it was revealed that profits from the sale of Recruit Cosmos

\section{Medicines committees disclose links with drug companies}

\section{London}

For the first time, the British government has revealed details of the personal financial links between members of the bodies that oversee the safety and licensing of drugs and the pharmaceutical industry. The links are extensive. But the government maintains that commercial interests do not influence the advice it receives from these bodies. It is making the details public simply "to avoid public concern that the interests might influence their decisions". But publication seems likely to have the opposite effect.

Under the ethical code to which members must adhere, consultancies, fee-paid work or shareholdings must be declared.

Of the 21 members of the Committee on Safety of Medicines, which advises the government on licensing drugs and monitoring those on the market, 13 have declared interests. And of the 24 members of the Medicines Commission, 16 have declared interests.

The ethical code requires that if a member has any interest in a product under consideration, that member cannot take part in the proceedings except, at the chairman's discretion, to answer questions by other members.

The Minister for Health, David Mellor, says that having links with industry helps members to keep in touch with important aspects of drug development. And in the ethical code, too, it is stated that it is desirable that members have an understanding of the work of industry and practical experience of scientific problems of product development.

Next year will bring more glasnost within the drugs watchdogs: indirect links with industry, such as the sponsoring of research in a member's department, will also be made public. But there the openness will end; a spokesman for the Department of Health says it will not give in to demands that the amounts of money involved be disclosed or that members should be made to sever financial links

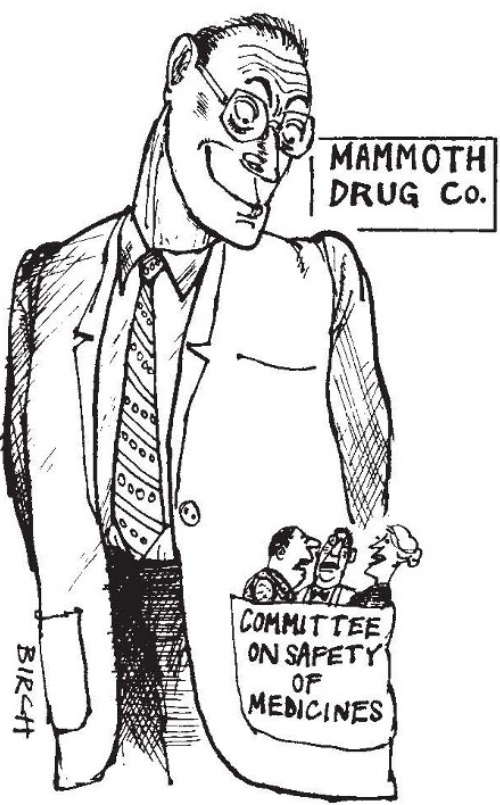

with industry while advising the government. Only with these concessions can advice to the government be impartial, says Dr Joe Collier, a pharmacologist at St George's Hospital Medical School in London, who has campaigned for the register of interests to be made public. He says that by requiring that the chairmen of the commission and the committees sever all links with industry, the government is acknowledging that such links do influence decision-making. Christine McGourty shares had been deposited in his account. Shinto's resignation followed closely that of Kiichi Miyazawa, finance minister and deputy prime minister, who had to step down because of contradictory statements he made over his role in the Recruit affair.

Details of the profiteering began to leak out in July, shortly after a vice-mayor was fired for his role in the share deal. The scandal escalated when an official of Recruit was videotaped offering an envelope stuffed with cash to an opposition member of the Diet who was looking into the affair.

The videotape was subsequently broadcast on national television and the Recruit official has been indicted on charges of attempted bribery.

Former Prime Minister Yasuhiro Nakasone is one of the key figures in the Recruit scandal. Two of his secretaries and a former accountant of his supporters' organization bought a total of 29,000 Recruit Cosmos shares. And several cabinet members of Nakasone's former administration, including the present Prime Minister, Noboru Takeshita, and Shintaro Abe, secretary general of the ruling Liberal Democratic Party, have been alleged by the Japanese media to have links with the share dealing. But Nakasone is maintaining a strict policy of "no comment".

The resignations of Finance Minister Miyazawa and NTT chairman Shinto may have profound consequences for Japan. Miyazawa and Abe were the two strongest candidates to replace Takeshita when his two-year term as prime minister ends next year. But Miyazawa's hopes have now been dashed and his faction within the ruling party has been severely weakened. Shinto led the privatization of NTT with Nakasone's backing, and his resignation may result in greater pressure from the Ministry of Post and Telecommunications to break up the telecommunications monopoly, which still controls all but a few per cent of the domestic market.

But in the long run, the scandal may more seriously undermine the reputation of Japan's government and industry with partners overseas just at the time when both are seeking greater influence.

David Swinbanks

\section{Living coelacanths}

\section{London}

THE living coelacanth Latimeria chalumnae was discovered 50 years ago this week, on 23 December 1938 (see page 727 of this issue). A special exhibition to mark the occasion opens on 22 December at the British Museum (Natural History) in London. Models and memorabilia of the discovery will be on display, and a video film of living coelacanths in their natural habitat will be shown.

Henry Gee 